\title{
（5）免疫学的機序による輸血副作用
}

\author{
埼玉医科大学総合医療センター輸血部
}

前 田 平 生

従来よりアレルギー反応は, 症状の発現する時間, 関与する抗体の免疫グロブリンクラス, 感作 $\mathrm{T}$ 細胞か 否かにより, I 型 ( $\mathrm{IgE}$ 依存型), II 型 (細胞傷害型), III型 (免疫複合体型)，IV型（細胞性免疫型）に分類さ れてきた(表 1 )。この分類は，あまりにも単純化され ているが, 免疫学的機序による輸血副作用の理解のた めにこの分類に沿って概説する.

\section{1. アレルギー反応の分類}

I 型は, 肥満細胞に結合した IgEに抗原（アレルゲ ン）が反応すると，ヒスタミンをはじめとして顆粒内 化学物質を放出し, それらは即時型反応を起こすと共 に走化因子として炎症部位に白血球を集め遅発型反応 を起こす。アレルゲンを含んだ血液を輸血されると， 莖麻疹, 気管支攣縮, 血圧低下, ときには全身性アナ
フィラキシーショックになることがある.

II型のアレルギーは，異型輸血で見られるように， 赤血球に抗体 (IgG, IgM) が結合し, 補体が活性化さ れ，溶血反応と共に，活性化補体成分 (C3a，C5a) が 血中に放出され, 発熱, 悪寒, 胸痛, 血圧低下などの 症状を呈する。細胞膜抗原・抗体複合体による直接的 (Fcレセプター, 補体レセプターを介する), 間接的(活 性化補体成分）炎症性サイトカインの産生による。

III型アレルギーは, 血清成分に対して抗体が反応し， 可溶性免疫複合体が生成され, 補体が活性化されるこ とにより発症する. IgA 欠損症のアナフィラキシー様 反応が代表的である. IgE 抗体は必ずしも関与してい ないが，I 型によるアナフィラキシー反応と類似の症 状を呈し，活性化補体成分 (C3a，C5a) が肥満細胞か

表 1 アレルギー反応の分類とそれによる疾患

\begin{tabular}{|c|c|c|c|c|}
\hline 型 & I 型 & II 型 & III型 & IV型 \\
\hline 名称 & $\begin{array}{c}\text { 即時型 } \\
\text { アナフィトラシ型 } \\
\text { IgE 依存型 }\end{array}$ & $\begin{array}{l}\text { 細胞傷害型 } \\
\text { 細胞融解型 }\end{array}$ & $\begin{array}{l}\text { 免疫複合体型 } \\
\text { アルサス型 }\end{array}$ & $\begin{array}{l}\text { 細胞免疫型 } \\
\text { 羊延型 } \\
\text { ツベルクリ型 }\end{array}$ \\
\hline 抗体 & $\operatorname{IgE}$-抗体 & $\begin{array}{l}\operatorname{IgM} \\
\operatorname{IgG}\end{array}$ & IgG & $\mathrm{T}$ 細胞 \\
\hline 抗原 & (アレル因 & $\begin{array}{c}\text { 外因, 内因 } \\
\text { (細胞膜抗原) }\end{array}$ & $\begin{array}{l}\text { 外因, 内因 } \\
\text { (可溶性抗原) }\end{array}$ & 外因, 内因 \\
\hline 反応機序 & $\begin{array}{c}\text { (1)肥満細胞, 好塩基球 } \\
\text { 化学伝達物質放出 } \\
\text { (七ス多シ少 } \\
\text { ロイコトエン等) } \\
\text { 標的器官 } \\
\text { 平滑筋収縮 } \\
\text { 血管透過充進 } \\
\text { 血管拡張 }\end{array}$ & $\begin{array}{c}\text { (1)補体活性化 } \\
\text { (C3a, C5a, C567) } \\
\downarrow \\
\text { 標的細胞融解 } \\
\text { (2)補体活性化 } \\
\text { 免疫粘着, 貪食 } \\
\downarrow \text { 標的細胞傷害 } \\
\text { (3)抗原抗体複合体 } \\
\downarrow \\
\text { 嶺食細胞 } \\
\text { K細胞 } \\
\downarrow \\
\text { 標的細胞傷害 }\end{array}$ & $\begin{array}{c}\text { 血管壁, 組織内 } \\
\text { 可溶性免疫複合体 } \\
\text { (1)補体活性华 } \\
\text { (C3a, C5a, C567) } \\
\downarrow \\
\text { 貪食細胞 } \\
\text { 炎症反応 } \\
\text { 血管壁, 組織傷害 } \\
\text { (2)補体活性化 } \\
\text { アナフィラトキシン } \\
\text { (C3a, C5a) } \\
\text { 肥満細胞刺激 }\end{array}$ & $\begin{array}{c}\mathrm{T} \text { 細胞活性化 } \\
\text { (1)貪食細胞 } \\
\text { リソソ } \downarrow \text { 公酵素 } \\
\downarrow \\
\text { 組織傷害 } \\
\text { (2)キラーT細胞 } \\
\downarrow \\
\text { 標的細胞傷害 }\end{array}$ \\
\hline 代表的疾患 & 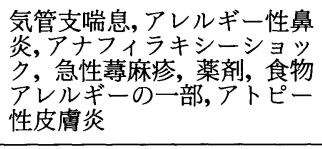 & $\begin{array}{l}\text { AIHA, 無顆粒球症, } \\
\text { Goodpasture 症候群 }\end{array}$ & $\begin{array}{l}\text { 過敏性肺臟炎, 気管支アスペ } \\
\text { ウギルス, SLE, 慢性䦳リ } \\
\text { ウマチ }\end{array}$ & $\begin{array}{l}\text { 感染, 慢性肉芽腫, 接触性皮 } \\
\text { 炎炎 }\end{array}$ \\
\hline 輸血副作用 & $\begin{array}{l}\text { アナフイラキシーショック } \\
\text { の一部(薬剤, 食物?) }\end{array}$ & $\begin{array}{l}\text { 血液型不適合輸血,抗白血球 } \\
\text { 抗体, 抗血小杭体 }\end{array}$ & 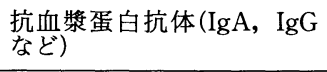 & 臟器移植拒絶反応, GVHD \\
\hline
\end{tabular}

\footnotetext{
エッセンシャル アレルギー・膠原病学 (粕川禮司, 牧野荘平編)より引用, 改変 ${ }^{1)}$
} 
らのヒスタミン，顆粒放出に関与していることが推定 される。

IV型は, ヘルパーT 細胞, キラーT 細胞, モノサイ ト/マクロファージを介した細胞, 臟器に対する傷害反 応である. 移植での拒絶反応, GVHD もこの機序によ る.

\section{2. 抗赤血球抗体}

抗赤血球抗体による溶血性副作用では，補体が活性 化されるか否かにより臨床症状は大きく異なる. ABO 型不適合輸血のように補体が活性化される場合は, 輸 血直後より血管内で溶血が起こり，同時に活性化補体 成分が血中に放出され, 多彩な臨床症状を呈する. 赤 血球抗原・抗体複合物により $\mathrm{FcR}+$ 細胞 (マクロ ファージなど) が活性化され, 炎症性サイトカイン(IL1, IL-6，TNF- $\alpha$ など）の産生により発熱・悪寒・戦 慄などの症状を呈する.また,アナフィラトキシン (C3 a, C5a), 血管収縮物質の産生により胸痛, 腰痛, 血圧 低下をきたし, 凝固系を六進することによりDIC を起 こしやすく，放置すれば急性腎不全に陥る。

一方, 補体が活性化されない場合は, 不適合赤血球 は血管外の細網内皮系の $\mathrm{FcR}+$ 細胞によりゆっくり と（～1 週間）処理をされ, 貧血, 黄疸を主症状とす る(II型アレルギー反応).

\section{3. 抗白血球・血小板抗体}

白血球，血小板に対する抗体(抗 HLA 抗体，抗顆粒 球抗体, 抗血小板抗体) によっても溶血性反応と同様 に FcR+細胞が活性化され, 炎症性サイトカインが産 生され, 発熱・悪寒・戦慄などの非溶血性発熱反応が 起こる(II型アレルギー反応).

また，標的細胞によっては，抗体が結合することに より，当該細胞が活性化され，特有の症状を呈するこ とがある (非心原性急性肺傷害)。

\section{4. 抗血漿蛋白抗体}

抗血漿蛋白抗体のなかで, IgA 欠損症における抗 IgA 抗体によるアナフィラキシー反応が有名である. 白人では検出感度以下の $\operatorname{IgA}$ 濃度の供血者は 500 2,000人に 1 人とされ, そのうちの約 $30 \%$ で抗 IgA 抗体 (IgG type) を有している。また，アレルギー 副作用を起こした患者のうち，8～18\%のみが抗 $\operatorname{Ig} \mathrm{A}$ 抗体（IgG type）を有していた。これとアナフィラキ シー反応の頻度（約 $1 / 10,000$ 件）を勘案すると，1）抗 $\operatorname{IgA}$ 抗体を有している患者の大部分はアナフィラキ シー反応を起こさない,2）アレルギー反応の原因の大 部分は抗 $\operatorname{Ig} \mathrm{A}$ 抗体によるものではない, ことが推定さ
れる.

IgA の他に, 多型性を示す血漿蛋白として, IgG，ア ルブミン, ハプトグロブリン, トランスフェリン, a 1 アンチトリプシン, C3，C4などがあるが，これら血漿 蛋白アロタイプに対する抗体産生ならびに輸血副作用 への関与についてはよく分かっていない（III型アレル ギー反応).

\section{5. 抗アレルゲン抗体 $(\mathrm{IgE})$}

患者が特異的 IgE 抗体を保有し, 輸血血液中に対応 アレルゲンが存在するときに発症し, 萇麻疹程度の軽 度のものからアナフィラキシーショックのような重症 型まである.アレルゲンとして薬剈（ペニシリン，セ ファロスポリンなど), 食物, 血液バッグ消毒滅菌剤・ 材料などが想定されるが原因物質の確認は困難であ る.また，逆に輸血血液中に特異的 IgE 抗体があり， 患者は輸血により受身感作され，それに対応するアレ ルゲンを注射または攝取したときに発症する可能性も ある.しかし,一般的に $\operatorname{IgE}$ 抗体の血中半減期は 2 日 程度であり，肥満細胞に結合した組織中においても 7 〜10日であること，また抗体量としては微量であるこ とを考えると後者の場合は考えにくい．また，アレル ギー反応を示した患者の $90 \%$ 以上は何らかの特異的 $\mathrm{IgE}$ 抗体を保有しているが，血液製剤中には $25 \%$ 程度 であることからアレルギー反応は供血者よりむしろ患 者のアトピー素因が原因である可能性が強い（I 型ア レルギー反応).

\section{6. 今後の課題}

非溶血性輸血副作用のうち重篤なものは, $\mathrm{ABO}$ 異 型輸血, アナフィラキシー反応である.このうち，ア ナフィラキシー反応に関しては，その多くが原因不明 であり, 免疫学的機序によるものがどの程度関与して いるのかもよく分かっていない.これの原因の究明の ためには，以下に掲げる課題が重要である。

1）輸血副作用の大規模調査

観察項目を統一して症状の種類, 発症時期, 輸血血 液製剂の種類などを調査し，血液製剤別に副作用の発 症頻度を正確に把握する．この際, 発症前後の患者検 体ならびに血液製剤を保存し，原因究明に資する（抗 血漿蛋白抗体の測定, 血液製剤中の各種サイトカイン, ケモカイン濃度の測定)。

2) $\operatorname{Ig} \mathrm{A}$ 濃度ならびに $\operatorname{IgG}, \operatorname{IgM}, \operatorname{IgE}$ 抗 $\operatorname{Ig} \mathrm{A}$ 抗体の 測定

ドナーならびに患者の血清 $\operatorname{Ig} A$ 濃度, $\operatorname{IgG}, \operatorname{IgM}, \operatorname{IgE}$ 抗 IgA 抗体を測定する. 特に IgE 抗 IgA 抗体のアナ 
フィラキシー反応への関与を明確にする.

3）久損または多型蛋白の精製と検査法の確立

IgA と同様に抗アロ蛋白抗体の測定法を確立する.

4）患者血清中の特異的 $\operatorname{IgE}$ 抗体の測定

アトピー素因のある患者においてアレルギー性副作 用がより高頻度に発症することが知られている。これ が, 特異的なアレルゲン（薬剤，食物アレルゲン，消 毒滅菌剤，血液バッグ・フィルター材料など）の輸注 によるものか, または, 輸血という多種多様な外来抗 原の免疫による非特異反応 (IgE 抗体産生の元進) なの か見きわめる必要がある。

$$
\text { まとめ }
$$

我々の副作用調査では, アレルギー・アナフィラキ シー反応は血小板輸血では血漿輸血の約10倍の頻度で 発生している.この頻度の差は, 両製剤の輸血を受け ている患者の背景因子の差によるのか, あるいは, 血 小板製剂の製造, 保存, 輸血の過程でアナフィラキシー
惹起物質が産生されることによるのか, 両面からの検 討が必要である。

\section{文 献}

1）牧野荘平：アレルギー反応.エッセンシャルアレ ルギー・膠原病学 (第 2 版). 粕川禮司, 牧野荘平 編 著. 医歯薬出版, 東京, 1996, p. 33-50.

2) Vamvakas, E.C. and Pineda, A.A.: Allergic and anaphylactic reactions. In: Popovsky, M. A., ed al. Transfusion reactions. Bethesda, AABB Press, 1996, 81-123.

3) Greenberger, P.A.: Plasma anaphylaxis and immediate type reactions. In : Rossi, E.C., et al. eds. Principles of transfusion medicine. 2nd ed. Baltimore, Williams \& Wilkins, 1996, p. 765771.

4) Wilhelm, D., Kluter, H., Klouche, M., Kirchner, H. : Impact of allergy screening for blood donors: Relationship to nonhemolytic transfusion reactions. Vox Sang., 69 : 217-221, 1995. 